\title{
VISUAL ACUITY AND DEPRESSIVE SYMPTOMS BEFORE AND AFTER FIRST EYE CATARACT SURGERY IN ELDERLY PATIENTS
}

Filip Radotic1, Nela Djonovic², Tatjana Sarenac-Vulovic 3 , Suncica Sreckovic 3 , Mirjana Petrovic-Janicijevic ${ }^{3}$, Maja Zivkovic 4

IUniversity of Kragujevac, Serbia, Faculty of Medical Sciences

2 University of Kragujevac, Serbia, Faculty of Medical Sciences, Department of Hygiene and ecology Institute of Public Health "Kragujevac", Kragujevac, Serbia

${ }^{3}$ University of Kragujevac, Serbia, Faculty of Medical Sciences, Department of Ophthalmology

Ophthalmology Clinic, Clinical Center "Kragujevac", Kragujevac, Serbia

${ }^{4}$ Ophthalmology Clinic, Clinical Center "Nis", Nis, Serbia

\section{VIDNA OŠTRINA I DEPRESIVNI SIMPTOMI PRE I POSLE PRVE OPERACIJE KATARAKTE KOD STARIJIH PACIJENATA}

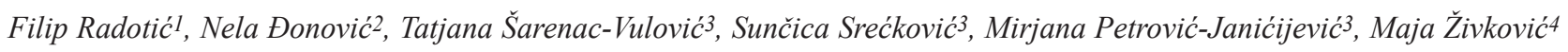 \\ IUniverzitet u Kragujevcu, Srbija, Fakultet medicinskih nauka \\ 2Univerzitet u Kragujevcu, Srbija, Fakultet medicinskih nauka, Katedra za higijenu i ekologiju \\ Institut za javno zdravlje Kragujevac, Kragujevac \\ ${ }^{3}$ Univerzitet u Kragujevcu, Srbija, Fakultet medicinskih nauka, Katedra za oftalmologiju \\ Klinika za očne bolesti, Klinički centar Kragujevac, Kragujevac \\ ${ }^{4}$ Klinika za očne bolesti, Klinički centar Niš, Niš
}

\section{ABSTRACT}

Aim. The aim of this research is to determine the potential impact of visual acuity on the occurrence of depressive symptoms in elderly patients before and after first eye cataract surgery, using the method of phacoemulsification.

Methods. The study lasted from May 2015 until May 2016 in the Eye Clinics, Clinical Centre "Kragujevac", Serbia. The total number of patients was 435, 234 men and 201 women. The patients who participated in the study were required to complete the GDS-15 scale. The GDS-15 scale was filled out twice, two weeks prior to surgery and four weeks after surgery.

Results. Statistical analysis showed that a significant difference exists in the level of visual acuity before and after surgery $(p<0.001)$. The results of the GDS-15 scale before and after cataract surgery indicated a significant difference $(p<0.003)$. Further group testing of depressive symptoms before and after surgery has shown: without symptoms $(p<0.003)$, mild symptoms $(p<0.002)$, moderate symptoms $(p<0.001)$ and severe symptoms $(p<0.004)$. The visual acuity in the non-operated eye has an important role in depressive symptoms before $(p<0.002)$ and after $(p<0.001)$ cataract surgery.

Conclusions. The study found that a statistically significant difference exists between the loss of visual acuity and the occurrence of depressive symptoms before and after first eye cataract surgery. Visual acuity is a very important factor in reducing depressive symptoms in older patients.

KEY WORDS: cataract, visual acuity, depressive symptoms

\section{SAŽETAK}

Cilj. Cilj istraživanja je da se determiniše potencijalni uticaj vidne oštrine na pojavu depresivnih simptoma kod starijih pacijenata pre $i$ posle prve operacije katarakte metodom fakoemulzifikacije.

Metode. Studija je trajala od maja 2015. do maja 2016. godine. Studija je sprovedena na očnoj klinici Kliničkog centra Kragujevac. Ukupan broj pacijenata bio je 435, $i$ to 234 muškarca, a 201 žena. Participanti studije popunjavali su GDS-15 upitnik nakon dve i nakon četiri nedelje posle prve operacije katarakte.

Rezultati. Statistička analiza pokazala je da postoji signifikantna razlika između nivoa vidne oštrine pre i posle operacije katarakte $(p<0.001)$. Rezultati GDS-15 skale pre $i$ posle operacije katarakte ukazuju na signifikantnu značajnost $(p<0.003)$. Dalje testiranje GDS-15 skale obavljeno je poređenjem različitih grupa depresivnih simptoma pre i posle operacije katarakte, $i$ to: bez simptoma depresije $(p<0.003)$, blagi simptomi $(p<0.002)$, umereni simptomi $(p<0.001)$ i ozbiljni simptomi depresije $(p<0.004)$. Analiziran je $i$ uticaj vidne oštrine neoperisanog oka. Neoperisano oko ima značajnu ulogu u pojavi depresivnih simptoma pre $(p<0.002) i$ nakon $(p<0.001)$ operacije katarakte.

Zaključak. Studija je ustanovila signifikantnu povezanost između gubitka vidne oštrine i pojave depresivnih simptoma pre i posle prve operacije katarakte kod starijih pacijenata. Vidna oštrina može da bude značajan faktor u redukovanju pojave depresivnih simptoma kod pacijenata operisanih od katarakte.

KLJUČNE RE ČI: katarakta, vidna oštrina, depresivni simptomi 


\section{INTRODUCTION}

Vision loss among the elderly is a major health care problem. Approximately one person in three has some form of vision-reducing eye disease by the age of 65 (1). Senile cataract continues to be the main cause of visual impairment and blindness in the world $(2,3)$. Cataract prevalence increases with age. The prevalence of cataracts also increases with age in developing countries (4).

Cataracts are a common cause of vision impairment among the elderly, but surgery is effective in restoring vision (5). Cataracts typically progress slowly to cause vision loss, and are potentially blinding if untreated (6). Depending on the type of cataract, and its progression, during the 6-12 month waiting period for surgery patients need to continually adapt to the loss of visual acuity $(5,7,8)$.

Phased loss of vision and complete loss can have a major impact on patients who are diagnosed senile cataract. Depression symptoms are present in patients from the time of intraocular lens blur (gradual loss of visual acuity) to the surgical intervention (1).

Recent studies have shown a close correlation between a patient's level of visual acuity and depressive symptoms before and after cataract surgery (9-13).

The level of visual acuity of the non-operated eye is an important element in the level of depressive symptoms (14-16).

The aim of this research is to determine the potential impact of visual acuity on the occurrence of depressive symptoms in elderly patients before and after first eye cataract surgery.

\section{METHODS}

\section{Sample}

Of the 435 patients participating in this study, 234 were men (53.8\%) and 201 women (46.2\%). The age structure ranged from 62 years to 95 years.

To obtain power level of 0.8 at minimum significance level of 0.05 and a large effect size (Cohen's d = 0.3), each group would required at least 139 patients for one-tailed and for two-tailed at least 176 patients (17).

The criteria for selection of the participants were based on the following: diagnosed with senile cataracts; first cataract surgery; without other ocular and systemic disease (18-20). This study did not take into consideration patients who already had an operation for cataracts and were awaiting for further cataract surgery.

\section{Procedures}

The study lasted from May 2015 until May 2016 in the Eye Clinics, Clinical Centre "Kragujevac", Serbia.
Before any information was collected, informed written consent was obtained from each participant. Participation was entirely voluntary and patients were informed that they could withdraw from the study at any time without consequence for their cataract treatment. Patients who agreed to be part of the research, with the help of researchers, completed a Geriatric Depression Scale. The GDS scale was filled out twice, two weeks prior to surgery and four weeks after surgery. A similar procedure was used in the previous studies $(9,11)$.

\section{Instruments}

In the research we used a short Geriatric Depression Scale with 15 questions (GDS-15) that derived from the 30 -item GDS and is one of the most widely used instruments for screening for depression among older adults (21-26). The GDS-15 has been translated into 27 languages. In the translation from English to Serbian, the person who translated the GDS was Emilija Dubljanin Raspopovic, MD, Clinical Center of Serbia, Clinics for Physical Medicine and Rehabilitation, Belgrade, Serbia (27). The short scale is more easily used by ill patients, and mildly to moderately demented patients, who have short attention spans and/or feel easily fatigued. It takes about 5 to 7 minutes to complete (28-30). The GDS scale is significantly successful in differentiating depressed from non-depressed adults (31-34).

\section{Statistical analysis}

All statistical analyses were performed using the SPSS 20.0 software. Descriptive statistics were used to summarize all variables of interest. The Shapiro-Wilk test of normality in all tested variables was $p<0.05$, which indicates that non-parametric tests should be used in further comparative statistical analysis. In this study we used the following comparative statistical procedures: the Wilcoxon rank-sum test, Mann-Whitney test and KruskalWallis test. We used in this research Cohen's d 0.3 and statistical power level of 0.8 and probability level 0.05 .

\section{RESULTS}

From the total number of patients (435) visual acuity before surgery was sorted in the range: $0.1-0.3$ (387 patients, $88.9 \%$ ) and $0.4-0.6$ (48 patients, $11 \%)$. After surgical intervention there was an increased level of visual acuity in the range: $0.1-0.3$ (12 patients, $2.8 \%), 0.4-0.7$ (90 patients, 20.7\%) and most of the patients after the intervention had a visual acuity ranged $0.8-1.0$ (333 patients, 76.6\%). Presented in Fig. 1.

The level of visual acuity on the non-operated eye was in the range: $0.1-0.5$ (246 patients, 56.6\%) and $0.6-1.0$ (189 patients, $43.5 \%)$. 


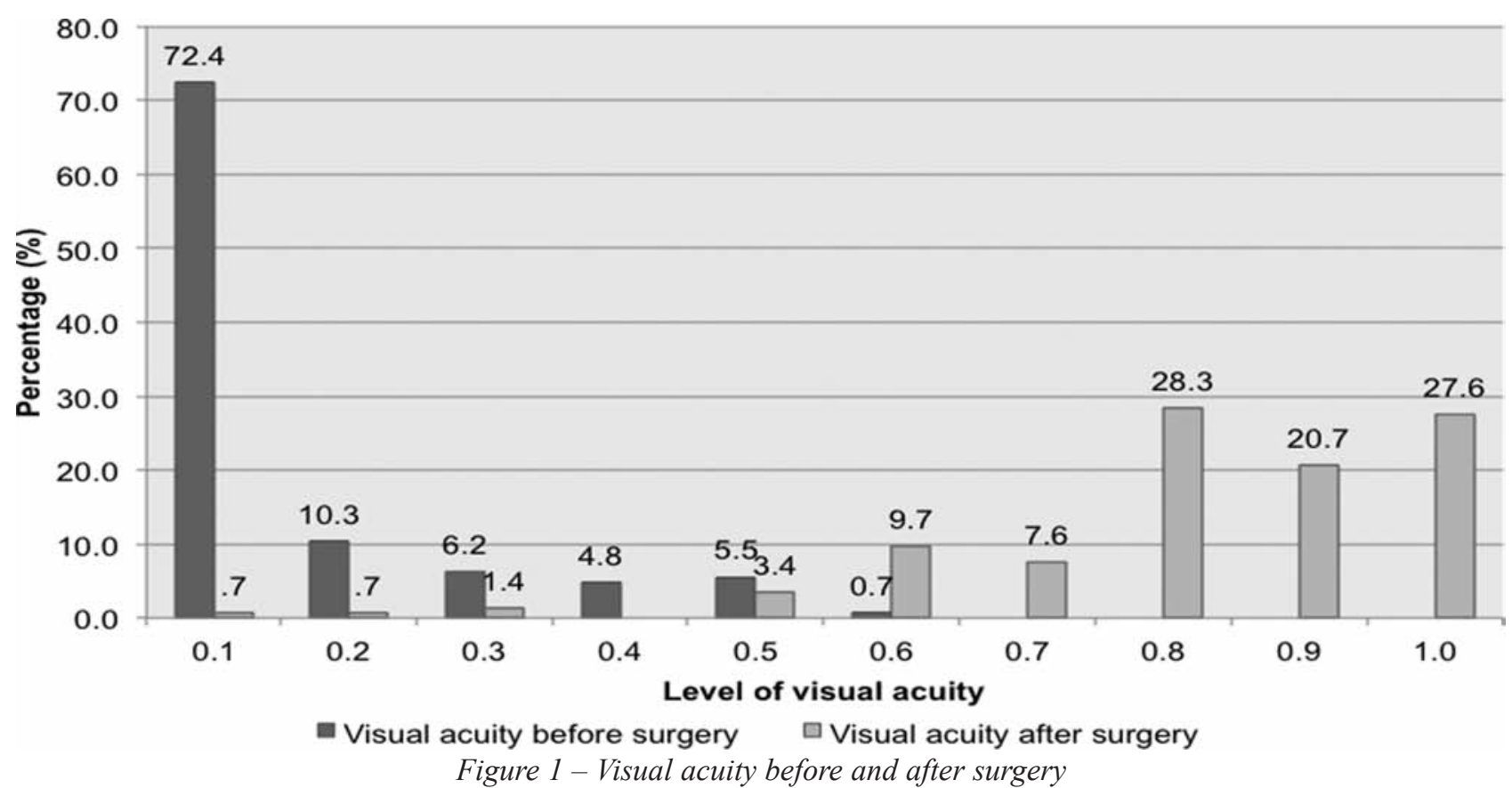

The GDS-15 scale before surgery showed a high level of mild (197 patients, $45.29 \%$ ) and moderate (94 patients, $21.61 \%$ ) depressive symptoms, and also showed the relative number of patients without depressive symptoms (105 patients, 24.14\%). After surgical intervention the GDS-15 scale results were a decreasing tendency for mild (108 patients, $24.83 \%$ ) and moderate (38 patients, $8.74 \%$ ) depressive symptoms and a significant increase of nondepressive symptoms (278 patients, 63.91\%). Presented in Fig. 2.

The Wilcoxon rank-sum test showed a significant difference in visual acuity before and after cataract surgery $(\mathrm{p}<0.001)$.

The result of the GDS-15 scale before and after cataract surgery, by applying the Wilcoxon rank-sum test, determined a statistically significant difference $(\mathrm{p}<0.003)$. Observing the individual groups of depressive symptoms based on GDS-15 scales revealed statistical significance before and after cataract surgery. With further testing of

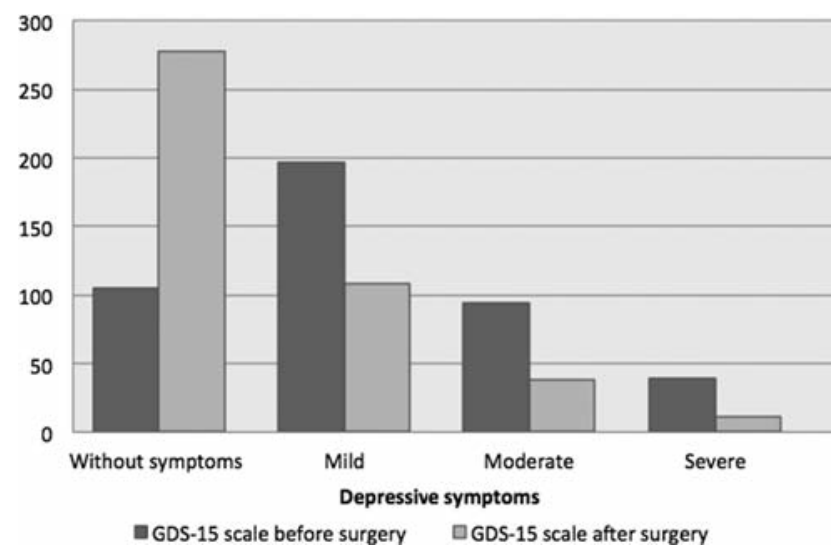

Figure 2 -Depressive symptoms before and after surgery depressive symptoms (before and after surgery) in groups, we came to the following results: without symptoms $(\mathrm{p}<0.003)$, mild symptoms $(\mathrm{p}<0.002)$, moderate symptoms $(p<0.001)$ and severe symptoms $(p<0.004)$.

The Kruskal-Wallis test indicated that the level of visual acuity in the non-operated eye has an important role in depressive symptoms before $(\mathrm{p}<0.002)$ and after $(\mathrm{p}<0.001)$ cataract surgery.

Further statistical analysis established that there was no significant difference between the gender of patients and their level of visual acuity nor between gender and depressive symptoms before and after cataract surgery.

A comprenhensive view of all statistical analyses is presented in table 1 .

\section{DISCUSSION}

This study found that a significant difference exists between the loss of visual acuity and the occurrence of depressive symptoms before and after first eye cataract surgery in elderly patients. Also previous studies have found a link between depressive symptoms and level of visual acuity (9-12,14,15,24,35-43).

Our study also found that a significant difference exists between the level of depressive symptoms before and after cataract surgery, and in this way that the level of depressive symptoms was significantly increased before surgical intervention and significantly decreased after.

An analysis of the impact of the visual acuity of the non-operated eye on the symptoms of depression showed that the level of visual acuity of the non-operated eye significantly affects odepressive symptoms before and after cataract surgery. 
Table 1. A comprehensive view of all statistical analyses

\begin{tabular}{|c|c|c|c|c|}
\hline Examined variables & Examined groups & Z & $\mathrm{P}$ & $\mathrm{R}$ \\
\hline $\begin{array}{c}\text { Visual acuity before vs. } \\
\text { after surgery }\end{array}$ & visual acuity before and after surgery & 18.083 & $<0.001$ & 0.613 \\
\hline $\begin{array}{l}\text { GDS-15 before and } \\
\text { after surgery }\end{array}$ & GDS-15 before and after surgery & 13.032 & $<0.003$ & 0.451 \\
\hline \multirow{4}{*}{$\begin{array}{l}\text { GDS-15 } \\
\text { between groups }\end{array}$} & $\begin{array}{c}\text { without symptoms before and after } \\
\text { surgery }\end{array}$ & 9.552 & $<0.003$ & 0.323 \\
\hline & $\begin{array}{c}\text { mild symptoms before and after } \\
\text { surgery }\end{array}$ & 8.187 & $<0.002$ & 0.277 \\
\hline & $\begin{array}{c}\text { moderate symptoms before and after } \\
\text { surgery }\end{array}$ & 5.140 & $<0.001$ & 0.174 \\
\hline & $\begin{array}{c}\text { severe symptoms before and after } \\
\text { surgery }\end{array}$ & 5.477 & $<0.004$ & 0.185 \\
\hline \multirow{2}{*}{$\begin{array}{c}\text { Visual acuity non-operated } \\
\text { eye vs. depression } \\
\text { symptoms }\end{array}$} & $\begin{array}{l}\text { non-operated eye vs. depression } \\
\text { symptoms before surgery }\end{array}$ & $c^{2}=43.095$ & $<0.002$ & \\
\hline & $\begin{array}{c}\text { non-operated eye vs. depression } \\
\text { symptoms after surgery }\end{array}$ & $\mathrm{c}^{2}=48.944$ & $<0.001$ & \\
\hline
\end{tabular}

Cataracts remain as one of the main causes of visual impairment in the world, and the associated visual impairment has been shown to have significant impact on quality of life $(44,45)$.

Therefore, visual acuity is a very important factor in reducing depressive symptoms in older patients.

\section{ABBREVIATIONS:}

GDS-Geriatric Depression Scale

\section{REFERENCES}

1. Quillen DA. Common causes of vision loss in elderly patients. Am Fam Physician 1999; 60: 99-108.

2. Buch H, Vinding T, Nielsen NV. Prevalence and causes of visual impairment according to World Health Organization and United States criteria in an aged, urban Scandinavian population: the Copenhagen City Eye Study. Ophthalmology 2001; 108: 2347-57.

3. Murthy GVS, Vashist P, John N, Pokharel G, Ellwein LB. Prevelence and causes of visual impairment and blindness in older adults in an area of India with a high cataract surgical rate. Ophthalmic Epidemiol 2010; 17: 185-95.

4. Brian G, Taylor H. Cataract blindness-challenges for the 21 st century. Bull World Health Organ 2001; 79: 249-56.

5. Blumenthal M. Cataract surgery. Community Eye Health Int Cent Eye Health 2002; 15: 27.

6. Congdon N, Vingerling JR, Klein BEK, et al. Prevalence of cataract and pseudophakia/aphakia among adults in the United States. Arch Ophthalmol 2004; 122: 487-94.

7. Bollinger KE, Langston RHS. What can patients expect from cataract surgery? Cleve Clin J Med 2008; 75: 193-6, 199-200.
8. Rovner BW, Casten R. Stability of visual acuity measurement in depression. Am J Geriatr Psychiatry Off J Am Assoc Geriatr Psychiatry 2005; 13: 255-8.

9. Freeman EE, Gresset J, Djafari F, et al. Cataractrelated vision loss and depression in a cohort of patients awaiting cataract surgery. Can J Ophthalmol J Can Ophtalmol 2009; 44: 171-6.

10. Mitsonis CI, Mitropoulos PA, Dimopoulos NP, et al. Anxiety and depression in cataract surgery: a pilot study in the elderly. Psychol Rep 2006; 99: 257-65.

11. Fraser ML, Meuleners LB, Lee AH, Ng JQ, Morlet N. Vision, quality of life and depressive symptoms after first eye cataract surgery. Psychogeriatr Off J Jpn Psychogeriatr Soc 2013; 13: 237-43.

12. Fraser ML, Meuleners LB, Ng JQ, Morlet N. Driver self-regulation and depressive symptoms in cataract patients awaiting surgery: a cross-sectional study. BMC Ophthalmol 2013; 13: 45.

13. Morse JS, Schallhorn SC, Hettinger K, Tanzer D. Role of depressive symptoms in patient satisfaction with visual quality after laser in situ keratomileusis. J Cataract Refract Surg 2009; 35: 341-6.

14. Lee BS, Munoz BE, West SK, Gower EW. Functional improvement after one- and two-eye cataract surgery in the Salisbury Eye Evaluation. Ophthalmology 2013; 120: 949-55.

15. To KG, Meuleners LB, Fraser ML, et al. The impact of cataract surgery on depressive symptoms for bilateral cataract patients in Ho Chi Minh City, Vietnam. Int Psychogeriatr IPA 2014; 26: 307-13.

16. Acosta-Rojas ER, Comas M, Sala M, Castells X. Association between visual impairment and patientreported visual disability at different stages of cataract surgery. Ophthalmic Epidemiol 2006; 13: 299-307.

17. Cohen J. A power primer. Psychol Bull 1992; 112: 155-9. 
18. Jovanović S, Zlatanović G, Jovanović Z, Radotić F. Clinical profile of presumed and definitive ocular sarcoidosis. Srp Arh Celok Lek 2013; 141: 13-6.

19. Lazarevic M, Petrovic D, Mladenovic V, Jovanovic S, Radotic F. Thyroid function in haemodialysis patients. Med Cas 2015; 49: 78-84.

20. Andjelic G, Jovanovic S, Pesic S, et al. The efficacy of a posterior sub-tenon's capsule triamcinolone injection in patients with non-infectious intermediate uveitis and posterior uveitis. Serbian J Exp Clin Res [Internet]. 2016 [cited 2017 Feb 15]. Available from: http://www.degruyter.com/view/j/sjecr.ahead-ofprint/sjecr-2016-0046/sjecr-2016-0046.xml

21. Yesavage JA, Brink TL, Rose TL, et al. Development and validation of a geriatric depression screening scale: a preliminary report. J Psychiatr Res 1982-1983; 17: $37-49$.

22. Segulin N, Deponte A. The evaluation of depression in the elderly: a modification of the Geriatric Depression Scale (GDS). Arch Gerontol Geriatr 2007; 44: 105-12.

23. Kurlowicz L, Greenberg SA. The Geriatric Depression Scale (GDS). AJN Am J Nurs 2007; 107: 67-8.

24. Torres RM, Miralles R, Garcia-Caselles MP, et al. Observational scale and geriatric depression scale of Yesavage to identify depressive symptoms in older patients. Arch Gerontol Geriatr Suppl 2004: 437-42.

25. Fountoulakis KN, Tsolaki M, Iacovides A, et al. The validation of the short form of the Geriatric Depression Scale (GDS) in Greece. Aging Milan Italy 1999; 11: 367-72.

26. Sheikh JI, Yesavage JA, Brooks JO, et al. Proposed factor structure of the Geriatric Depression Scale. Int Psychogeriatr 1991; 3: 23-8.

27. Dubljanin Raspopovic E. Serbian Version of the Geriatric Depression Scale [Internet]. Stanford University. [cited 2017 Feb 15]. Available from: http://web.stanford.edu/ yesavage/Serbian.html

28. Weintraub D, Oehlberg KA, Katz IR, Stern MB. Test characteristics of the 15-item geriatric depression scale and Hamilton depression rating scale in Parkinson disease. Am J Geriatr Psychiatry Off J Am Assoc Geriatr Psychiatry 2006; 14: 169-75.

29. Burke WJ, Roccaforte WH, Wengel SP. The short form of the Geriatric Depression Scale: a comparison with the 30-item form. J Geriatr Psychiatry Neurol 1991; 4: $173-8$.

30. Vinkers DJ, Gussekloo J, Stek ML, Westendorp RGJ, Van Der Mast RC. The 15-item Geriatric Depression Scale (GDS-15) detects changes in depressive symptoms after a major negative life event. The Leiden 85-plus Study. Int J Geriatr Psychiatry 2004; 19: 80-4.

31. Kurlowicz L. The geriatric depression scale (GDS). Insight Am Soc Ophthalmic Regist Nurses 2000; 25: 18-9.

32. Kurlowicz L. The Geriatric Depression Scale (GDS). Geriatr Nurs N Y N 1999; 20: 212-3.
33. Nyunt MSZ, Fones C, Niti M, Ng T-P. Criterion-based validity and reliability of the Geriatric Depression Screening Scale (GDS-15) in a large validation sample of community-living Asian older adults. Aging Ment Health 2009; 13: 376-82.

34. Ishihara T, Terada S. Geriatric Depression Scale (GDS). Nihon Rinsho Jpn J Clin Med 2011;69: 455-8.

35. Van der Aa HP, Comijs HC, Penninx BW, van Rens GHMB, van Nispen RMA. Major depressive and anxiety disorders in visually impaired older adults. Invest Ophthalmol Vis Sci 2015; 56: 849-54.

36. Qian Y, Glaser T, Esterberg E, Acharya NR. Depression and visual functioning in patients with ocular inflammatory disease. Am J Ophthalmol 2012; 153: 370-8.

37. Kulkarni KM, Mayer JR, Lorenzana LL, Myers JS, Spaeth GL. Visual field staging systems in glaucoma and the activities of daily living. Am J Ophthalmol 2012; 154: 445-51.

38. Rovner BW, Casten RJ. Activity loss and depression in age-related macular degeneration. Am J Geriatr Psychiatry Off J Am Assoc Geriatr Psychiatry 2002; 10: 305-10.

39. Pop-Jordanova N, Ristova J, Loleska S. Depression in ophthalmological patients. Pril Makedon Akad Na Nauk Umet Oddelenie Za Biološki Med Nauki Contrib Maced Acad Sci Arts Sect Biol Med Sci 2014; 35: 53-8.

40. Rovner BW, Casten RJ, Hegel MT, et al. Low vision depression prevention trial in age-related macular degeneration: a randomized clinical trial. Ophthalmology 2014; 121: 2204-11.

41. Green C, Goodfellow J, Kubie J. Eye care in the elderly. Aust Fam Physician 2014; 43: 447-50.

42. Senra H, Barbosa F, Ferreira P, et al. Psychologic Adjustment to Irreversible Vision Loss in Adults: A Systematic Review. Ophthalmology 2015; 122: 851-61

43. Zlatanović GD, Jovanović SV, Živković ML, Zlatanović ML, Srećković SB, Radotić FM. The efficacy of novel therapeutic modalities of isolated ocular vasculitis vs ocular vasculitis as a systemic disease. Med Glas Off Publ Med Assoc Zenica-Doboj Cant Bosnia Herzeg 2012; 9: 66-73.

44. Knudtson MD. Age-Related Eye Disease, Quality of Life, and Functional Activity. Arch Ophthalmol 2005; 123: 807.

45. Thylefors B, Négrel AD, Pararajasegaram R, Dadzie KY. Global data on blindness. Bull World Health Organ 1995; 73: 115-21. 